\title{
Bryophyte and polypore richness and indicators in relation to type, age and decay stage of coarse woody debris of Picea abies
}

\section{Guntis Brūmelis, Evita Oḷehnoviča, Undīne Šūba, Agita Treimane, Sintija Inne, Egita Zviedre, Didzis Elferts, Mārtiņš Dakša, Didzis Tjarve}

Faculty of Biology, University of Latvia, Academic Centre for Natural Sciences, Jelgavas 1, Rīga LV-1004, Latvia

${ }^{\star}$ Corresponding author, E-mail: guntis.brumelis@lu.lv

\begin{abstract}
Coarse woody debris (CWD), which is in low supply in intensively managed forest, is an essential habitat for many species of bryophytes, fungi and insects. We investigated richness of bryophyte and polypore species on CWD of Norway spruce Picea abies (L.) Karst. in relation to CWD type, size, decay stage and age since mortality. We also identified indicator species for the bryophyte and polypore communities on dead trees in various decay stages. CWD age since mortality was determined to assess the time period of potential colonization by the indicator species. The study was conducted in Latvia, located in the hemi-boreal forest zone, where such information was generally lacking. The larger part of spruce CWD was in early decay stages, due to the legacy of forest management and recent disturbance events. The maximum age of spruce CWD was 48 years, and age of the majority of CWD pieces in advanced decay stages was 20 to 40 years. The estimated ages of CWD suggest a more rapid decay rate in the mesotrophic habitat studied in the Eastern Baltic region than reported previously for northern Scandinavia and mountainous regions. Bryophyte species richness was significantly affected by CWD diameter, type (higher on snapped logs) and decay stage (lowest in initial decay stage). Polypore species richness was significantly lower on snags, and higher on logs in early decay stages. A succession of epixlyic species was shown from common polypore species Fomitopsis pinicola and Trichaptum abietinum at start of wood decay to indicator bryophytes like Nowellia curvifolia in early decay stages after loss of bark, Lepidozia reptans and Jamesoniella autumnalis in mid stages and Herzogiella seligeri with epigeous species in late decay stages.
\end{abstract}

Key words: biodiversity, dead wood, epixylic species, forest, Picea abies, succession. Abbreviations: CWD, coarse woody debris; DBH, diameter at breast height.

\section{Introduction}

Forest ecosystems in the boreal forest zone have adapted to natural disturbances (Stokland 2001; Kuuluvainen Aakala 2011) that cause tree mortality by fire, wind, insects, fungi and other agents. These disturbances occur at various scales, creating heterogenous patterns of multiple successions (Kuuluvainen 2002). Coarse woody debris (CWD) includes snags, stumps, logs, and branches, all of which provide habitat for a multitude of species. About one-fourth of species dwelling in boreal forest are considered to be dependent on coarse woody debris as a habitat (Siitonen et al. 2000). Species diversity of saproxylic species in a forest stand depends on the amount, species, type, size and decay stage of CWD, and also spatial and temporal continuity (Siitonen 2001). In a natural boreal woodland dominated by Picea abies, continuous recruitment of dead wood can ensure its continuous availability in all stages of decay (Jonsson 2000; Kuuluvainen et al. 2001). Threatened species of polypores in spruce forest are generally confined to oldgrowth stands with CWD amounts $>20 \mathrm{~m}^{3} \mathrm{ha}^{-1}$ (Penttilä et al. 2004). However, for hepatics, dispersal might not be limiting and preference for CWD substrate quality can be wide (Laaka-Lindberg et al. 2005). Forest management based on clearcut harvest at rotation age typically causes decreased amounts, size and diversity of CWD, and hence also diversity of saproxylic species (Ylisirniö et al. 2012). In contrast, young to mid-aged first-generation forest stands that have naturally regenerated and are non-intensively managed (no thinning) can host a wide diversity of structures, including CWD, which are important for biological diversity (Lõhmus, Lõhmus 2008). Higher species richness of bryophytes has been observed on logs with a larger diameter, which however tend to be in short supply in managed boreal woodland (Kruys et al. 1999).

Epixylic species have variable preference for CWD substrate type and decay stage, resulting in colonizationextinction dynamics (Jönsson et al. 2008). Thus, for management of biological diversity, information is needed on residence time of particular decay stages of CWD (Zielonka 2006a) and the associated communities of various organism groups. For example, diversity of typical 
epixylic bryophyte species is known to be higher on logs in mid stages of decay (Kushnevskaya et al. 2007), but there is insufficient information on the period of time that a log will occur in a required decay stage for particular species. Mean times for complete decay of logs of Norway spruce Picea abies have been estimated as 60 years in Southern Sweden (Ranius et al. 2004) and 100 years in south-central Scandinavia (Storaunet, Rolstad 2002). Decay rate of snags compared to logs is much slower, and decay rate has a linear relationship with time after fall of snag or living tree (Storaunet, Rolstad 2002). The rate of decay of CWD for a tree species depends of mode of origin (e.g. snag versus log), bole diameter (Holeksa et al. 2008) and other factors like environmental conditions (Ranius et al. 2004). Also height above ground of a log is related (negatively) to decay stage, and hence to diversity of saproxylic species (Botting, DeLong 2009).

Amounts of CWD in Latvia are relatively high (according to National Forest Inventory data, $\sim 17.5 \mathrm{~m}^{3}$ $\mathrm{ha}^{-1}$ ), which might be explained by relatively non-intensive forest management (e.g. less thinning and dead wood removal) and a recent major storm event in 2005. While the amounts of CWD in Latvia are high relative to those in many other European countries, the amounts of large CWD (> $30 \mathrm{~cm}$ diameter) are low (Madzule et al. 2012). The literature on deadwood decay in relation to both age since tree mortality and successions of organism groups is not sufficient and particularly for the eastern Baltic region, excepting some studies (Vasiliauskas et al. 2004; Lõhmus et al. 2007; Rajandu et al. 2009; Preikša et al. 2016). The eastern Baltic region represents the transition zone between boreal and temperate forest zones, where decay rates might be hypothesized to be more rapid due to the more temperate climate, than in Northern Scandinavia and alpine forest ecosystems, thus limiting the time period for suitable substrate for colonization by epixylic species. Previous studies on bryophyte and polypore communities on CWD had not studied the relationship with CWD age since mortality. Information including CWD age, decay stage and bryophyte and polypore communities is needed to estimate the period of time that CWD can act a substrate for these species, and hence the turnover rate that is required to maintain continuity. The aims of the study were to determine (1) relationships between age (time since tree mortality) and decay stage for different types of CWD, and (2) effect of diameter, type and decay stage of CWD on bryophyte and polypore species richness and (3) preference of bryophyte and polypore species (indicator species) for decay stage of logs.

\section{Materials and methods}

\section{Site description}

The study was carried out in two locations in the central part of Latvia: the Kemeri National Park west of the City of Riga and a managed forest area near the village Turkalne.
The climate is characterized by cool summers (mean 17.0 ${ }^{\circ} \mathrm{C}$ in July), warm winters (mean $-4.6{ }^{\circ} \mathrm{C}$ in January) and abundant precipitation (mean $667 \mathrm{~mm}$ annually; data from the Latvian Environment, Geology and Meteorology Centre). The sampled forests were dominated by Norway spruce Picea abies (L.) Karst. mixed with Scots pine Pinus sylvestris L. and birch Betula pendula L. and Betula pubescens L. Forest growth conditions were mesoeutrophic on moist mineral soils.

\section{Field data collection}

The study was conducted in the years 2012 to 2014 in four stands in the Kemeri National Park and three in the Turkalne site. In each site the stands were located within a $1.5 \mathrm{~km}$ radius. The stands were selected randomly from the Latvian State Forest Register with selection criteria as mature or over-mature spruce stands on mesic soils. CWD was abundant in three of the stands and all of the stands in the Turkalne area. In these stands, 15 circular plots with radius $15 \mathrm{~m}$ were established at the Kemeri site and four at the Turkalne site (Fig. 1). Location of plots was determined randomly using coordinates. If coarse woody debris was not found in the selected location, plot centre was chosen at base of the closest piece of CWD. The plots contained 4 to 32 dead spruce trees, and all contained snags, logs and stumps. In the remaining stand in the Kemeri site, as CWD was scarce and scattered, essentially all CWD in that stand was sampled (48 CWD pieces). In total, 40 snapped logs, 55 tipped logs, 25 snags and 42 stumps were sampled in the Kemeri site and eight snapped logs, 14 tipped logs, six snags and eight stumps in the Turkalne site.

In the plots, length and diameter $1.3 \mathrm{~m}$ from tree base were determined for each CWD piece (tipped logs,

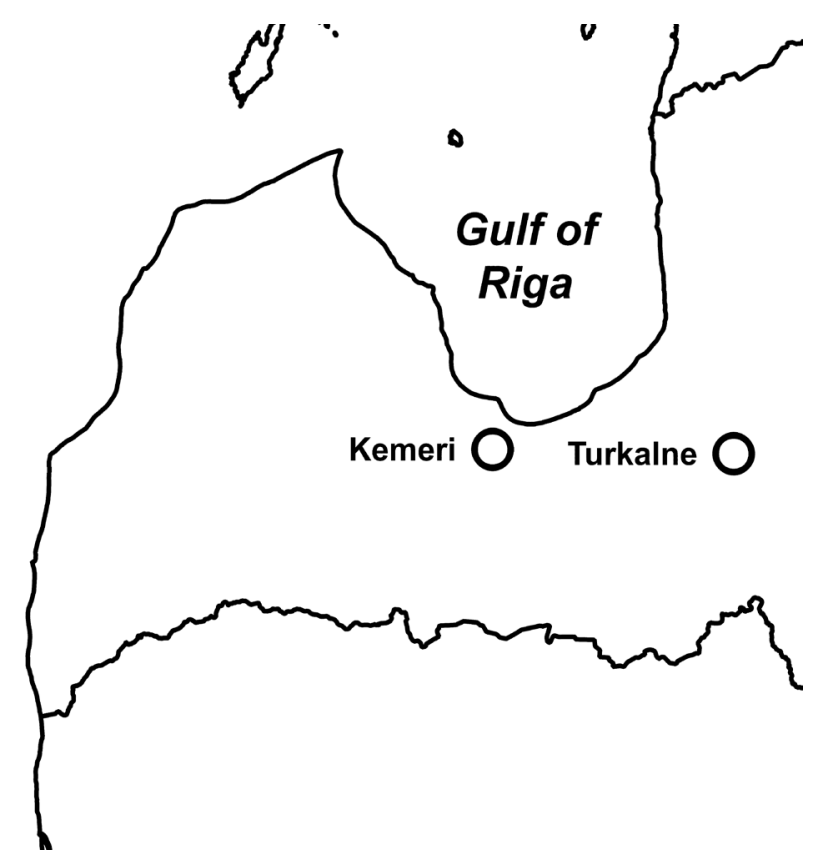

Fig. 1. Location of study sites. 
snapped logs, snags and stumps) with origin in the plot. CWD was defined as having a minimal diameter $\geq 10 \mathrm{~cm}$ at $1.3 \mathrm{~m}$ from base. Tipped logs included uprooted living trees with a wide root plate and uprooted snags and with a less discernible root plate. Snapped logs included trees that suffered stem breakage when living or as snags, due to wind or snow damage, or natural decay. Degree of decay (Table 1) was estimated on a 5-point scale for logs (Stokland 2001) and a 3-point scale for snags and stumps (Seedre et al. 2013). The decay stages 1 to 3 are similar for both of these decay scales; presumably, a snag or high stump in a higher decay stage is unlikely to exist in a vertical form, and short stumps in advanced decay stage would be difficult to recognize. If a log was divided in sections, then they were considered together. All bryophytes and polypores on pieces of course woody debris were recorded. Snapped logs and their stumps were treated separately as CWD pieces.

A disc was removed from each log by handsaw or chainsaw. A core using a borer or a disc section using a handsaw was removed from each snag. Cores were obtained from ten of the nearest living spruce trees for cross-dating to establish age of mortality. In cases where logs were in advanced stages and discs could not be taken, weaker proxies needed to be used. In those cases, discs were removed from adjacent spruce advance growth to estimate time of death from year of growth release; if this was not possible, the time of mortality was estimated from year of release of adjacent overstorey spruce trees.

\section{Determination of time of mortality of dead trees}

The collected wood samples (discs and cores) were dried at room temperature. Cores from living trees were glued in grooves of wood planks and then sanded. For CWD discs, about 2-cm wide paths from pith to bark were either sanded, or when very decayed and brittle, smoothed with a sharp scalpel. Discs from advance growth were sanded. Tree ring widths of cores and discs were measured on a Lintab 3 table.

To estimate time of mortality of CWD, tree ring series from each sample were cross-dated with chronologies estimated from living trees in the respective stands. Crossdating was conducted using the programme COFECHA (Grissino-Mayer 2001). In cases when wood was too decayed to distinguish tree rings, age of mortality was determined by a sharp and sustained increase in tree ring width in advance growth located near base (stump) of the CWD piece, or if not present, then in the closest 2 to 3 overstorey trees.

\section{Statistical analysis}

A cumulative link mixed model was used to test influence of CWD age, diameter, type and their interaction on the decay stage (ordinal variable). In addition, linear mixed effects models were used to test if age of CWD differed between types and between decay stages. Sampling plot was used as random factor to account for possible correlations between observations coming from the same plot. Type II Wald $\chi^{2}$ tests were used to test the significance of fixed factors. If a fixed factor with more than two levels showed significant effect, multiple comparisons (Tukey contrasts) were done to compare levels by pairs. Species accumulation curves derived using the sample-based rarefaction method in package vegan (Oksanen et al. 2016) indicated that an appropriate sample size of CWD pieces was reached. Poisson generalized mixed effects models (GLMMs) were used to test effect of CWD type, diameter, length, age and decay stage on bryophyte and polypore richness. Binomial GLMMs were used to test effect of decay stage on frequency of occurrence of bryophyte and polypore species found on at least 10 logs (tipped and snapped treated together). This analysis was not conducted for snags and stumps due to low sample size among the decay classes. For the statistical analysis software R 3.2.3 (R Core Team, 2015) was used. Mixed effects models were fitted using the lme4 package (Bates et al. 2015) and $p$-values for fixed factors calculated with the car package (Fox, Weisberg 2011). The Package multcomp (Hothorn et al. 2008) was used for multiple comparisons, the package ordinal (Christensen 2015) for cumulative link mixed model.

Table 1. Decay stages of logs, snags and stumps. ${ }^{\star}$, modified from Stokland (2001); ${ }^{\star *}$, modified from Seedre et al. (2013)

\begin{tabular}{lll}
$\begin{array}{l}\text { Type } \\
\text { Logs }\end{array}$ & Decay class & $\begin{array}{l}\text { Description } \\
\text { Recently dead. Bark intact. Little fungal. Wood intact, hard. }\end{array}$ \\
& 2 & $\begin{array}{l}\text { Bark loose, partially missing to only traces remaining. Wood partly decaying .knife } \\
\text { penetration }<3 \mathrm{~cm} \text { depth). }\end{array}$ \\
& 3 & $\begin{array}{l}\text { Some traces of bark to no bark. Moderately decayed (knife penetration }>3 \mathrm{~cm} \text { depth). Wood } \\
\text { core is still hard and log is round. }\end{array}$ \\
& $\begin{array}{l}\text { Very decayed, rotten throughout. Round cross-section of log is lost. } \\
\text { Almost fully decayed and becoming part of the forest floor. }\end{array}$ \\
\hline Snags and stumps & $\begin{array}{l}\text { Bark intact. Wood intact, hard. Twigs present. } \\
\text { Bark partially missing to only traces remaining. Wood partly decaying, some soft portions. } \\
2\end{array}$ & $\begin{array}{l}\text { No twigs. } \\
\text { No bark to some traces of bark. Wood mostly soft No twigs. }\end{array}$ \\
\hline 3 &
\end{tabular}




\section{Results}

A total of 196 pieces of spruce coarse woody debris (including 49 snapped logs, 69 tipped logs, 31 snags and 50 stumps) were described. The stumps in almost all cases represented the bases of snapped logs, i.e. not wood removal. The greater part (75\%) of the logs were in decay stages 1 or 2. Mean diameter at breast height $(\mathrm{DBH})$ of all logs and snags was $28.1 \mathrm{~cm}$; of these $44 \%$ had $\mathrm{DBH} \geq 30 \mathrm{~cm}$. About $90 \%$ of the logs plus snags in decay stages 1 and 2 were successfully cross-dated. However, this could be achieved only for $40 \%$ of those in advanced decay stages 3 to 5, as in many cases wood discs could not be collected and the weaker proxies were unsuccessful. Maximum age of dated CWD was 48 years, for a snapped log. Age had significant effect ( $p=0.017$ ) on decay stage of logs, while diameter and type of log, and their interactions, had no significant effect (Fig. 2). Mean age of stumps of different decay stages significantly differed (Chi squared test, $p<0.01$ ), reaching mean age of 42 years in decay stage 3 . Most snags had age less than 10 years, with a few outliers at about 40 years. Age of snapped logs was higher in advancing decay stages from 1 to 3 , but was highly variable and the difference in age between decay stages was not significant. Age of snapped logs in decay stages 4 and 5 was mostly between 20 and 40 years. Tipped logs were almost all in decay stages 1 and 2 and age was significantly higher in logs with decay stage 2 . For each decay stage mean age did not significantly differ between CWD types.

A total of 53 bryophyte and 17 polypore species were observed on the sampled CWD pieces. Generalized linear mixed models showed significant effect of CWD type $\left(\chi^{2}=21.78 ; p<0.001\right)$ and diameter $\left(\chi^{2}=3.97 ; p=0.046\right)$ on bryophyte species richness. Grouping together all decay stages, richness was about two times higher (Tukey contrasts, $p<0.05$ ) on snapped logs compared to the other types (Fig. 3). Length and age had no significant effect on bryophyte species richness. Grouping both types of logs together, decay stage had significant effect $\left(\chi^{2}=84.47 ; p\right.$ $<0.001$ ) on bryophyte species richness, being 4 to 6 times lower in decay stage 1 compared to the other decay stages. For CWD in decay stage 2, bryophyte species richness was higher on logs compared to stumps, and for decay stage 1, higher on snapped logs compared to tipped logs (Table 2).

Of the bryophyte species found on at least 10 logs (threshold used for statistical analysis), none showed significant preference for logs in early decay stage 1 . Twenty-nine species were found most often on decay stages 2 and 3, of which the liverwort Nowellia curvifolia showed significant preference for these stages (Table 3). Less common species found in these decay stages included the protected liverwort species Riccardia palmata. Typical epiphytic bryophytes, like Ptilium pulcherrimum and Radula complanata also persisted on logs in decay stages 2 to 3. Epixylic species like Lepidozia reptans and Jamesoniella autumnalis showed significant preference for the more decayed stages 3 and 4 . Species more common on logs in advanced decay stage 5, but also found on less decayed logs, included epixylic species like Herzogiella seligeri (significantly), Tetraphis pellucida and Dicranum flagellare, along with epigeous species such as Dicranum polysetum. The upiquitous epixylic species Lophocolea heterophylla was found in all decay stages except decay stage 1 , as were common forest floor mosses like Pleurozium schreberi, Hylocomium splendens, Dicranum scoparium and Eurhynchium angustirete.

Polypore species richness was significantly affected by CWD type $\left(\chi^{2}=27.82 ; p<0.001\right)$, being significantly lower (Tukey's contrasts, $p<0.05$ ) on snags than on other CWD types (Fig. 4). Decay stage also had significant effect $\left(\chi^{2}=\right.$ 31.28; $p<0.001$ ); polypore species richness on logs in decay stage 1 and 2 was significantly greater than on logs with decay stage 3 and 4 . DBH, length and age had no significant effect. For coarse wood debris in decay stage 1, polypore

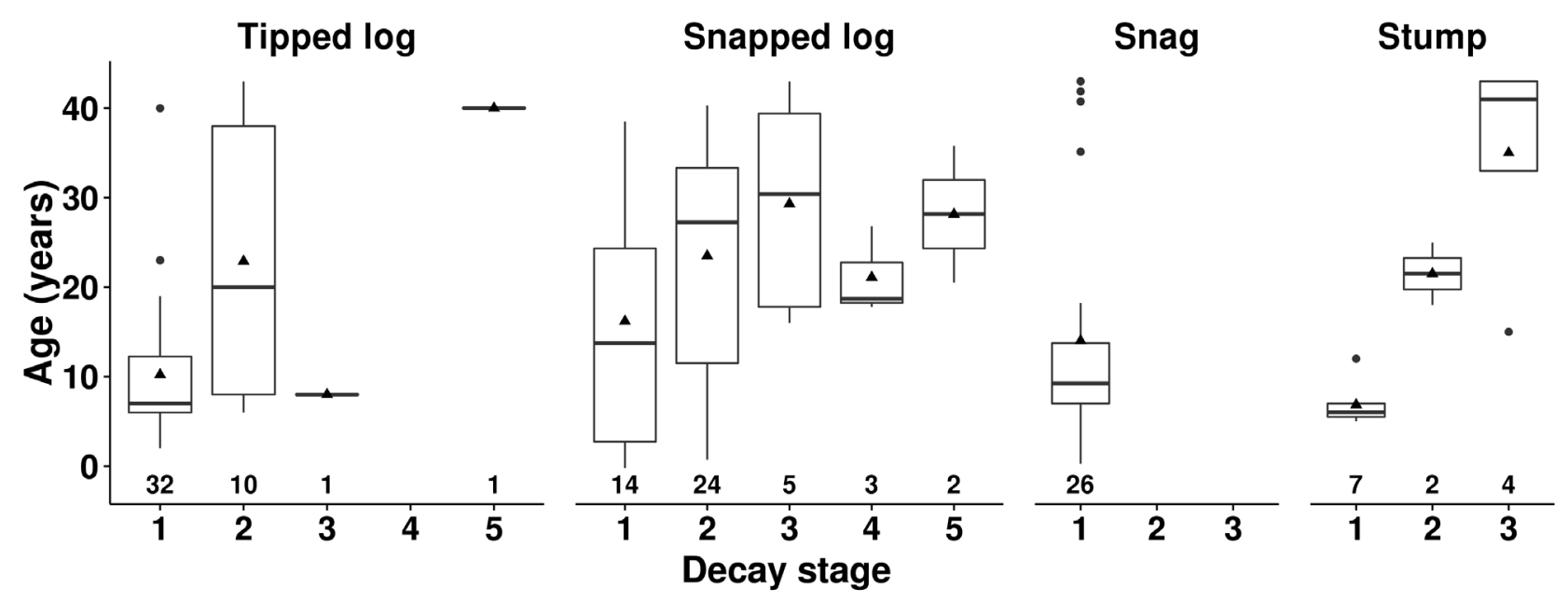

Fig. 2. Age of coarse woody debris in relation to type and decay stage. Triangles show mean value. Sample size given above $\mathrm{X}$ axis. 

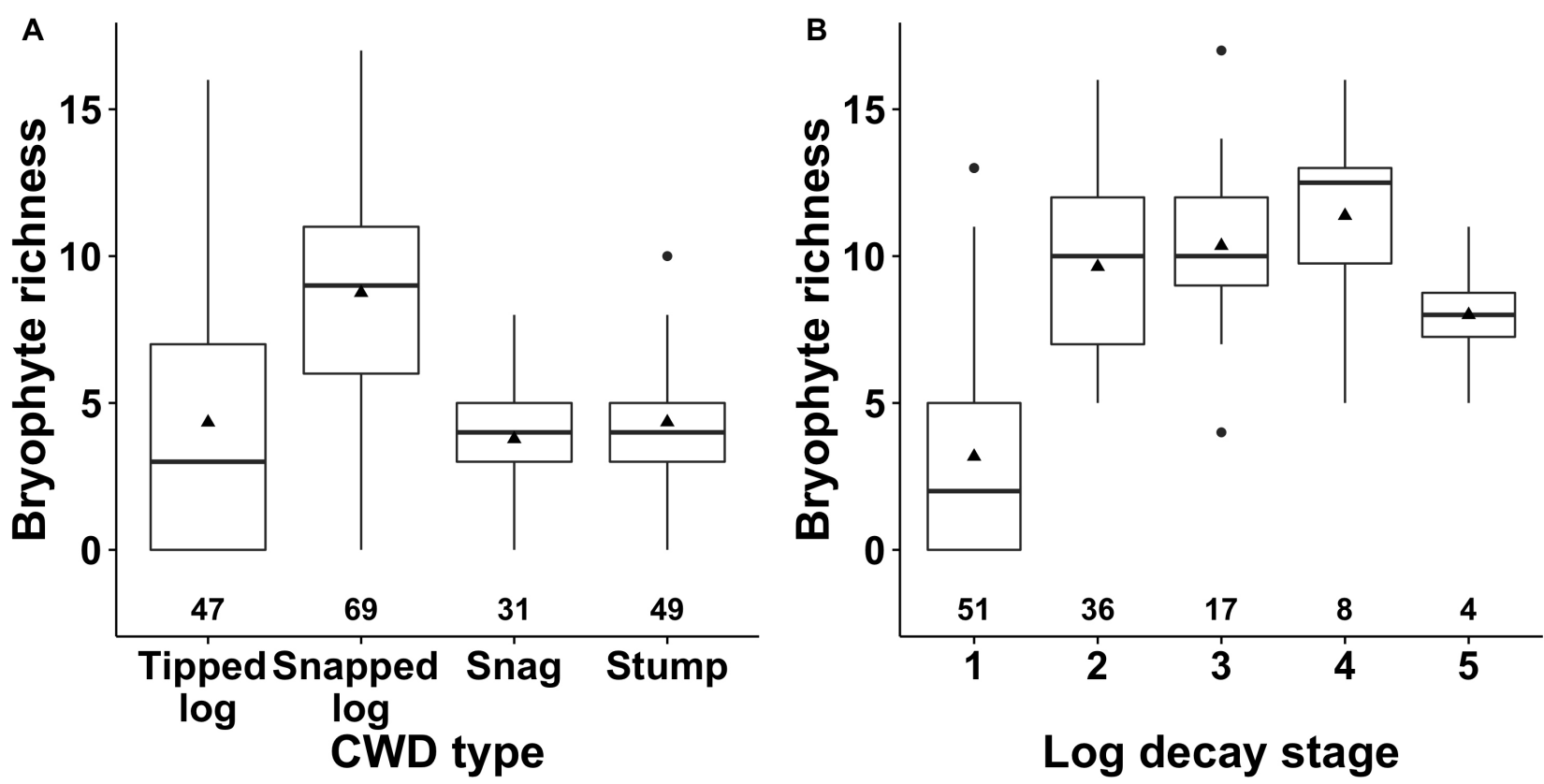

Fig. 3. Age of coarse woody debris in relation to type and decay stage. Triangles show mean value. Sample size given above $\mathrm{X}$ axis.

richness was significantly higher on logs compared to stumps (Table 2).

A total of 17 polypore species were recorded, of which only four occurred on at least $10 \mathrm{CWD}$ pieces and 10 occurred on three or less pieces. Polypore species generally showed preference for logs in early decay stages (Table 4 ). The most common species Fomitopsis pinicola, Trichaptum abietinum and Antrodia serialis were found on logs in decay stages 1 to 3 (4), but with highest occurrence in stages 1 or 2. Of these, Fomitopsis pinicola was ubiquitous, being found on 65 and $78 \%$ of logs in decay stages, respectively. The less

Table 2. Bryophyte and polypore richness in relation to coarse woody debris type and decay stage. Different letters indicate significant differences (Tukey contrasts, $p<0.05$ )

\begin{tabular}{|lllll|}
\hline $\begin{array}{l}\text { Bryophyte richness } \\
\text { Decay stage }\end{array}$ & $\begin{array}{l}\text { Tipped } \\
\text { logs }\end{array}$ & $\begin{array}{l}\text { Snapped } \\
\text { logs }\end{array}$ & Stumps & Snags \\
\hline 1 & $2.2 \mathrm{~B}$ & $5.1 \mathrm{~A}$ & $3.6 \mathrm{ABC}$ & $3.8 \mathrm{AC}$ \\
\hline 2 & $9.4 \mathrm{~A}$ & $10.3 \mathrm{~A}$ & $3.0 \mathrm{~B}$ & \\
\hline 3 & 10.8 & 4.0 & 4.2 & \\
\hline 4 & 11.1 & 12.0 & & \\
\hline 5 & 8.9 & 7.6 & & \\
\hline Polypore richness & & & \\
\hline Decay stage & Tipped & Snapped & Stumps & Snags \\
& logs & logs & & \\
\hline 1 & $2.0 \mathrm{~A}$ & $1.5 \mathrm{~A}$ & $1.3 \mathrm{~B}$ & $0.5 \mathrm{AB}$ \\
\hline 2 & 2.4 & 2.6 & 0.0 & \\
\hline 3 & 1.0 & 0.7 & 0.3 & \\
\hline 4 & 0.5 & 0.6 & & \\
\hline 5 & 0.0 & 0.2 & & \\
\hline
\end{tabular}

common species were generally lacking on logs with decay stages 3 to 5 . The same was true also for rare species in Latvia (Meiere 2002): Antrodiella citrinella (found on one log), Leptoporus mollis (one log), Oligoporus guttulatus (three logs), Oligoporus ptychogaster (two logs), Pycnoporellus fulgens (three logs), and Skeletocutis carneogrisea (seven logs).

\section{Discussion}

Highly overlapping range of CWD age between decay stages indicated that logs decay at different rates. We found no effect of diameter on age within a decay stage, and thus no evidence for effect of diameter on decay rate, in contrast to previous studies (Storaunet, Rolstad 2002; Shorohova, Kapitsa 2016). There was also no evidence that tipped logs, which are held above ground by a root plate, remain in initial decay stage 1 and 2 for a longer period of time than snapped logs. An unknown proportion of the snapped logs presumably existed as a snag for an unknown period of time before breakage, thereby increasing the variability of time required to reach a particular decay stage (Zielonka 2006a; Aakala 2010). Mean age of snags was slightly less than 10 years and maximum age was 48 years, which corresponds to previously estimated times since death and fall of snags of 22 years (Storaunet, Rolstad 2002) and 12 to 27 years (Aakala 2010). All sampled snags were in decay stage 1; presumably, they fell before wood became soft as in decay stage 2 .

Mean time to reach an advanced stage of decay of spruce logs was estimated to be 34 to 40 in the Midnorthern boreal regions of Sweden (Jonsson 2000; Kruys et al. 2002), similar to the results of our study, but less 
Table 3. Occurrence of bryophyte species on logs varying in decay stage. Proportion of logs within a decay stage inhabited by each species is given. Species with significantly higher occurrence in a particular decay stage are shown in bold. Substrate groups (Kushnevskaya et al. 2007): epf, epiphytic; epg, epigeous; epx, epixylic and g, generalist

\begin{tabular}{|c|c|c|c|c|c|c|c|c|}
\hline \multirow[t]{2}{*}{$\begin{array}{l}\text { Preferred decay } \\
\text { stage }\end{array}$} & \multirow[t]{2}{*}{ Species } & \multirow[t]{2}{*}{$\begin{array}{l}\text { Substrate } \\
\text { specificity }\end{array}$} & \multirow[t]{2}{*}{$\begin{array}{l}\text { Occurrence (total } \\
\text { number of logs) }\end{array}$} & \multicolumn{5}{|c|}{$\begin{array}{c}\text { Proportion of logs occupied (percent) in } \\
\text { decay stage } 1-5\end{array}$} \\
\hline & & & & 1 & 2 & 3 & 4 & 5 \\
\hline \multirow[t]{7}{*}{ Decay stage $2-3$} & Nowellia curvifolia & epx & 31 & 8 & 42 & 53 & 38 & 0 \\
\hline & Ptilidium pulcherrimum & epf & 43 & 21 & 58 & 41 & 50 & 0 \\
\hline & Sciuro-hypnum oedipodium & epg & 20 & 16 & 25 & 12 & 13 & 0 \\
\hline & Radula complanata & epf & 16 & 6 & 28 & 18 & 0 & 0 \\
\hline & Platygyrium repens & epf & 14 & 4 & 25 & 12 & 13 & 0 \\
\hline & Sanionia uncinata & $\mathrm{g}$ & 12 & 4 & 19 & 12 & 3 & 0 \\
\hline & Ptilium crista-castrensis & epg & 10 & 2 & 19 & 6 & 13 & 0 \\
\hline \multirow[t]{2}{*}{ Decay stage 3-4 } & Lepidozia reptans & epx & 19 & 4 & 11 & 47 & 63 & 0 \\
\hline & Jamesoniella autumnalis & epx & 14 & 2 & 11 & 29 & 50 & 0 \\
\hline \multirow[t]{5}{*}{ Decay stage 5} & Herzogiella seligeri & epx & 32 & 6 & 31 & 59 & 63 & 75 \\
\hline & Dicranum polysetum & epg & 20 & 2 & 19 & 29 & 50 & 75 \\
\hline & Brachythecium rutabulum & epg & 10 & 6 & 8 & 0 & 13 & 75 \\
\hline & Dicranum flagellare & epx & 10 & 4 & 11 & 11 & 13 & 25 \\
\hline & Tetraphis pellucida & epx & 10 & 8 & 6 & 6 & 13 & 50 \\
\hline \multirow[t]{10}{*}{ Decay stage $2-5$} & Lophocolea heterophylla & epx & 64 & 31 & 83 & 71 & 63 & 25 \\
\hline & Pleurozium schreberi & epg & 69 & 35 & 81 & 71 & 100 & 50 \\
\hline & Dicranum scoparium & epg & 68 & 22 & 81 & 94 & 100 & 100 \\
\hline & Eurhynchium angustirete & epg & 32 & 11 & 31 & 53 & 50 & 50 \\
\hline & Hylocomium splendens & epg & 62 & 24 & 67 & 94 & 88 & 75 \\
\hline & Hypnum cupressiforme & epg & 54 & 24 & 72 & 65 & 50 & 25 \\
\hline & Rhytidiadelphus triquetrus & epg & 52 & 18 & 64 & 82 & 50 & 50 \\
\hline & Plagiomnium affine & $\mathrm{g}$ & 20 & 10 & 22 & 18 & 38 & 25 \\
\hline & Plagiomnium ellipticum & epg & 18 & 6 & 22 & 18 & 25 & 50 \\
\hline & Rhodobryum roseum & epg & 11 & 0 & 19 & 12 & 13 & 25 \\
\hline
\end{tabular}
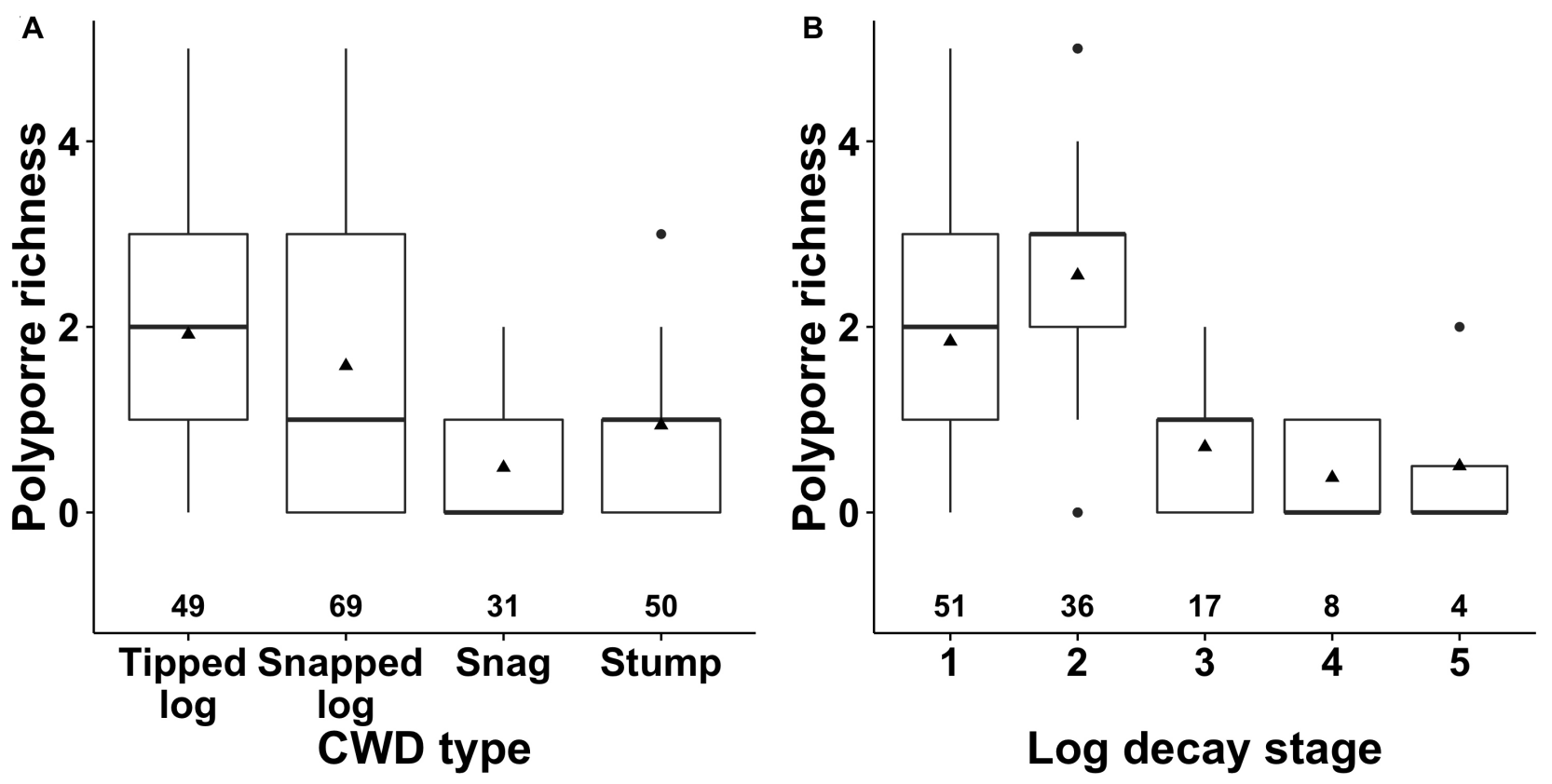

Fig. 4. Polypore richness on coarse woody debris in relation to type and decay stage. Triangles show mean value. Sample size given above $\mathrm{X}$ axis. 
Table 4. Occurrence of polypore species on logs varying in decay stage. Proportion of logs within a decay stage inhabited by each species is given. Species with significantly higher occurrence in a particular decay stage are shown in bold.

\begin{tabular}{llcccccc} 
Preferred decay & Species & Occurrence (total & \multicolumn{4}{c}{ Proportion of logs occupied (\%) } \\
\cline { 3 - 8 } stage & & number of logs) & $\mathbf{1}$ & $\mathbf{2}$ & $\mathbf{3}$ & $\mathbf{4}$ & $\mathbf{5}$ \\
Decay stage 1-2 & Fomitopsis pinicola & 70 & 65 & 78 & 41 & 25 & 0 \\
& Trichaptum abietinum & 54 & 62 & 56 & 12 & 0 & 0 \\
& Antrodia serialis & 27 & 18 & 42 & 12 & 13 & 0 \\
\hline & Ischnoderma benzoinum & 10 & 2 & 25 & 0 & 0
\end{tabular}

than the estimated 100 years in the mid-boreal region of Norway (Storaunet, Rolstad 2002), > 45 years in southern to northern boreal zones in Russia (Shorohova, Kapitsa 2016), and 70 to 80 years in the subalpine zone in Poland (Zielonka 2006a). The large discrepancy in rate of decay might be explained by differences due to vegetation zone, site type, CWD size (Shorohova, Kapitsa 2016) and the mortality agent. The decay rate in the hemiboreal vegetation zone, and particularly in richer site types, as in the present study, would be expected to be more rapid than in northern regions in poor site types. We did not observe a linear relationship between decay stage and age of CWD as previously assumed when calculating residence times of logs (Zielonka 2006b). Rather, snapped logs in advanced decay stages 3 to 5 had variable range of age (20 to 40 years), and there was no significant increase in age with decay stage. This might be explained by rapid decay through these stages until logs can no longer be recognized (Kruys et al. 2002; Aakala 2010).

The rarity of CWD in older age classes might be due to efficient past removal of dead wood or insufficient time since regeneration to have formed dead wood in later decay stages. In contrast the common occurrence of CWD in early decay stages suggests greater tree mortality in recent years. A wind storm in 2005 caused extensive wind throw and breakage throughout Latvia, and might have resulted in input of both fresh logs and fall of snags. According to State Forest Service data, the windstorm created a loss of 7.3 million $\mathrm{m}^{3}$, or input of $\sim 2.4 \mathrm{~m}^{3} \mathrm{ha}^{-1}$ of fresh CWD. According to National Forest Inventory data, the windstorm added 3.4 to $4.2 \mathrm{~m}^{3} \mathrm{~h}^{-1}$ CWD (Donis et al., unpublished data). In the studied sites the larger part of CWD was in early decay stages, particularly regarding tipped logs, which can be explained by increased input in recent years. Thus, wind can be a random factor that adds variability across regions in decay rate of CWD by reducing residence times of snags. However, in Latvia, the largest part of windthrown and wind snapped trees in commercial forest are removed during sanitation cuttings.

Bryophyte species richness was affected by CWD diameter, type and decay stage. The observed higher bryophyte species richness, and particularly that of redlisted species, on larger CWD might be due to larger area of available substrate, higher longevity, higher moistureholding capacity and/or less chance of overgrowing of logs by epigeous species (Kruys et al. 1999). The lower bryophyte species richness on tipped logs held above ground by a root plate, compared to snapped logs, might also be explained by a less favourable microclimate on logs held above ground, and by less chance of colonization by epigeous species (Botting, DeLong 2009). Mean bryophyte richness was lower on spruce logs in decay stage 1, likely due to greater number of species preferring more decayed logs as substrate, the generally poor epiphytic flora that survive on freshly dead wood, and the short period of time for colonization by epixylic species.

A succession of bryophyte species on logs was observed from epiphytic species and epigeous mosses found near tree base, to greater occurrence of epixylic species, and at advanced decay stages to typical ground mosses, as observed previously (Kushnevskaya et al. 2007). There were no species that could act as indicators of decay stage 1. Epiphytic, epigeous, epixylic and generalist species were all found on logs in this decay stage, but most with lower frequency of occurrence than on logs in later decay stages. The epixylic species can be divided into species that prefer less advanced stages after loss of bark (Nowellia curvifolia), mid stages (Lepidozia reptans and Jamesoniella autumnalis) and advanced stages (Herzogiella seligeri, Tetraphis pellucida and Dicranum flagellare). These species are not rare in Latvia, but of course will not occur in the absence of CWD, and thus diversity of decay stages of CWD is required to ensure suitable substrate as habitat. The similar mean age (about 30 years) of snapped logs in decay stages 2 to 5 suggests rapid transition between these stages, and a short time period of availability of suitable substrate for species requiring a particular decay stage. However, continued supply is guaranteed from logs in decay stage 1 (44\% of the logs randomly sampled in the studied territories), and further from snags that would supplement the logs in decay stage 1 (about $60 \%$ of the CWD pieces in decay stage 1). We found no effect of diameter of CWD on polypore species richness, as suggested in previous studies (Høiland, Bendiksen 1996; Sippola et al. 2001). This might be due to the generally impoverished number of species in the studied area - only 17, compared to 68 species observed in a similar study in eastern Finland (Sippola et al. 2001). The low polypore diversity may be due to lack of past temporal continuity of substrate (Siitonen 2001) due to removal of dead trees, which was suggested by the low 
amounts of CWD in late decay stages. It is also known that colonization of CWD by aggressive species like Fomitopsis pinicola is associated with lower species richness of polypore species (Bässler et al. 2016). Polypore utilization of logs generally occurs from initial bark loss to the stage of wood softening (Kruys et al. 1999), corresponding to decay stage 3 . The recorded polypore species generally colonized wood in an early stages of decay (decay stages 1 and 2). The common species (Fomitopsis pinicola, Trichaptum abietinum and Antrodia serialis) also occurred on logs in decay stages 3 and/or 4 suggesting plasticity in preference of a particular decay stage. Peak colonization of Antrodia serialis has been observed to occur in mid decay stages, but the species has little preference for log characteristics (Jönsson et al. 2008). The availability of CWD in adequate amounts with temporal and spatial continuity is needed to ensure substrate for species with colonization restraints (Jönsson et al. 2008). The recorded rare species in Latvia (Meiere 2002), such as Antrodiella citronella, Leptoporus mollis, Oligoporus guttulatus, O. ptychogaster, Pycnoporellus fulgens and Skeletocutis amorpha, were found only on logs in decay stages 1 and 2, suggesting that adequate supply of logs in these stages would be a structural indicator for habitat that has potential quality for maintaining species richness. The mean ages of tipped ( 20 years) and snapped $\operatorname{logs}(\sim 30$ years $)$ in logs of decay stage 2 suggest that polypores generally utilize logs with age up to 30 years as a substrate. However, wood-decaying fungi will persist on an individual log for a relatively short period of time and extinction on a log will likely not be followed by colonization (Jönsson et al. 2008). Polypore species richness is related to dead wood volume (Similä et al. 2006), which is likely to a precondition for continuous recruitment of CWD, and hence availability of substrate for colonization of polypore species. Recruitment of logs occurs as breakage of living trees and snags, and by windthrow of living trees. The lifespan of a snag created by mortality of a living tree is variable and may be as much as 40 years. Therefore, the mortality of a group of spruce trees by, for example, bark beetle Ips typographus, will likely add logs over a number of years, and as a result ensure CWD in various decay stages for a period of at least 10 years (mean life span of a snag).

\section{Conclusions}

The maximum age of a dated CWD piece was only 48 years, and most logs in the most advance decay stage 5 had age 30 to 40 years, suggesting more rapid decay in the hemi-boreal zone compared to northern and mountainous regions. In cases of more rapid decay rate of CWD, the time window for existence of suitable substrate for colonization by epixylic species would be shorter, increasing the importance of continuous supply of dead wood for continuity of substrate. In this regard, lack of past continuity might explain the low diversity of polypores recorded. A succession of bryophyte and polypore communities in relation to decay stage was shown. Polypore species preferred early stages of wood decay, while epiphytic bryophytes were replaced by epixylic species characteristic of early, mid and late stages. Epigeous bryophytes dominated the late stages of log decay. Residence times of potentially available substrate on logs for particular species need to be calculated as time since tree fall, as the stems can remain as snags for a highly variable period of time.

\section{Acknowledgements}

The study was supported by the research programme "The value and dynamic of Latvia's ecosystems under changing climate EVIDEnT". The help of Diāna Meiere in polypore identification was much appreciated. Permission to conduct research in protected areas was authorized by the Latvian Nature Conservation Agency. We value the discussions with Jānis Donis (Latvian State Forest Research Institute "Silava") on dead wood supply.

\section{References}

Aakala T. 2010. Coarse woody debris in late-successional Picea abies forests in northern Europe: variability in quantities and models of decay class dynamics. For. Ecol. Manage. 260: 770-779.

Bässler C., Müller J., Cadotte M.W., Heibl C., Bradtka J.H., Thorn S., Halbwachs H. 2016. Functional response of lignicolous fungal guilds to bark beetle deforestation. Ecol. Indicators 65 : 149-160.

Bates D., Mächler M., Bolker B.M., Walker S.C. 2015. Fitting linear mixed-effects models using lme4. J. Statist. Software 67: 1-48.

Botting R.S., DeLong C. 2009. Macrolichen and bryophyte responses to coarse woody debris characteristics in sub-boreal spruce forest. For. Ecol. Manage. 258: S85-S94.

Christensen R.H.B. 2015. Regression Models for Ordinal Data. https://cran.gis-lab.info/web/packages/ordinal/. Accessed 15 November 2016

Fox J., Weisberg S. 2011. An R Companion to Applied Regression. SAGE. $472 \mathrm{p}$.

Høiland K., Bendiksen E. 1996. Biodiversity of wood-inhabiting fungi in a boreal coniferous forest in Ser-Trendelag County, Central Norway. Nord. J. Bot. 16: 643-659.

Holeksa J., Zielonka T., Zywiec M. 2008. Modeling the decay of coarse woody debris in a subalpine Norway spruce forest of the West Carpathians, Poland. Can. J. For. Res. 38: 415-428.

Hothorn T., Bretz F., Westfall P. 2008. Simultaneous inference in general parametric models. Biom. J. 50: 346-363.

Jonsson B.G. 2000. Availability of coarse woody debris in a boreal old-growth Picea abies forest. J. Veget. Sci. 11: 51-56.

Jönsson M.T., Edman M., Jonsson B.G. 2008. Colonization and extinction patterns of wood-decaying fungi in a boreal oldgrowth Picea abies forest. J. Ecol. 96: 1065-1075.

Kruys N., Fries C., Jonsson B.G., Lämås T., Ståhl G. 1999. Woodinhabiting cryptogams on dead Norway spruce (Picea abies) trees in managed Swedish boreal forests. Can. J. For. Res. 29: 178-186.

Kruys N., Jonsson B.G., Ståhl G. 2002. A stage-based matriz model for decay-class dynamics of woody debris. Ecol. Appl. 12:773781 
Kushnevskaya H., Mirin D., Shorohova E. 2007. Patterns of epixylic vegetation on spruce logs in late-successional boreal forests. For. Ecol. Manage. 250: 25-33.

Kuuluvainen T. 2002. Natural variability of forests as a reference for restoring and managing biological diversity in boreal Fennoscandia. Silva Fenn. 36: 97-125.

Kuuluvainen T., Aakala T. 2011. Natural forest dynamics in boreal Fennoscandia: a review and classification. Silva Fenn. 45: 823-841.

Kuuluvainen T., Syrjänen K., Kalliola R. 2001. Logs in a pristine Picea abies forest: occurrence, decay stage distribution and spatial pattern. Ecol. Bull. 49: 105-113.

Laaka-Lindberg S., Pohjamo M., Korpelainen H. 2005. Niche breadth and niche overlap in three epixylic hepatics in a boreal old-growth forest, southern Finland. J. Bryol. 27: 119-127.

Lõhmus A., Lõhmus P. 2008. First-generation forests are not necessarily worse than long-term managed forests for lichens and bryophytes. Restor. Ecol. 16: 231-239.

Lõhmus A., Lõhmus P., Vellak K. 2007. Substratum diversity explains landscape-scale co-variation in the species-richness of bryophytes and lichens. Biol. Conserv. 135: 405-414.

Madzule L., Brumelis G., Tjarve D. 2012. Structures determining bryophyte species richness in a managed forest landscape in boreo-nemoral Europe. Biodivers. Conserv. 21: 437-450.

Meiere D. 2002. Checklist of polyphores of Latvia. Latvijas Veǵetācija 5: 7-41. /in Latvian/

Oksanen J., Blanchet F.G., Friendly M., Kindt R., Legendre P., McGlinn D., Minchin P.R., O'Hara R.B., Simpson G.L., Solymos P., Stevens M.H.H, Szoecs E., Wagner H. 2016. Package 'vegan'. https://github.com/vegandevs/vegan. https://cran.r-project. org/web/packages/vegan/ accessed 15 November 2016.

Penttilä R., Siitonen J., Kuusinen M. 2004. Polypore diversity in managed and old-growth boreal Picea abies forests in southern Finland. Biol. Conserv. 117: 271-283.

Preikša Z., Brazaitis G., Marozas V., Jaroszewicz B. 2016. Dead wood quality influences species diversity of rare cryptogams in temperate broadleaved forests. iForest Biogeosci. Forestry 9: 276-285.

R Core Team. 2015. R: A language and environment for statistical computing. R Foundation for Statistical Computing. https:// www.R-project.org/. 15 November 2016

Rajandu E., Kikas K., Paal J. 2009. Bryophytes and decaying wood in Hepatica site-type boreo-nemoral Pinus sylvestris forests in Southern Estonia. For. Ecol. Manage. 257: 994-1003.

Ranius T., Jonsson BG., Kruys N. 2004. Modeling dead wood in Fennoscandian old-growth forests dominated by Norway spruce. Can. J. For. Res. 34: 1025-1034.

Shorohova E., Kapitsa E. 2016. The decomposition rate of non-stem components of coarse woody debris (CWD) in European boreal forests mainly depends on site moisture and tree species. Eur. J. Forest Res. 135: 593-606.

Siitonen J. 2001. Forest management, coarse woody debris and saproxylic organisms: Fennoscandian boreal forests as an example. Ecol. Bull. 49: 11-41

Siitonen J., Martikainen P., Punttila P., Rauh J. 2000. Coarse woody debris and stand characteristics in mature managed and oldgrowth boreal mesic forests in southern Finland. For. Ecol. Manage. 128: 211-225.

Similä M., Kouki J., Mönkkönen M., Sippola A.-L., Huhta E. 2006. Co-variation and indicators of species diversity: Can richness of forest-dwelling species be predicted in northern boreal forests? Ecol. Indicators 6: 686-700.

Sippola A.-L., Lehesvirta T., Renvall P. 2001. Effects of selective logging on coarse woody debris and diversity of wooddecaying polypores in eastern Finland. Ecol. Bull. 49: 243-254.

Stokland J.N. 2001. The coarse woody debris profile: an archive of recent forest history and an important biodiversity indicator. Ecol. Bull. 49: 71-83

Storaunet K.O., Rolstad J. 2002. Time since death and fall of Norway spruce logs in old-growth and selectively cut boreal forest. Can. J. For. Res. 32: 1801-1812.

Vasiliauskas R., Vasiliauskas A., Stenlid J., Matelis A. 2004. Dead trees and protected polypores in unmanaged north-temperate forest stands of Lithuania. For. Ecol. Manage. 193: 355-370.

Ylisirniö A.-L., Penttila R.., Berglund H., Hallikainen V., Isaeva L., Kauhanen H., Koivula M., Mikkola K. 2012. Dead wood and polypore diversity in natural post-fire succession forests and managed stands - Lessons for biodiversity management in boreal forests. For. Ecol. Manage. 286: 16-27.

Zielonka T. 2006a. Quantity and decay stages of coarse woody debris in old-growth subalpine spruce forests of the western Carpathians, Poland. Can. J. For. Res. 36: 2614-2622.

Zielonka T. 2006b. When does dead wood turn into a substrate for spruce replacement? J. Veget. Sci. 17: 739-746. 